Article

\title{
Governance Challenges in Addressing Climatic Concerns in Coastal Asia and Africa
}

\author{
M. Anwar Hossen *, Md. Arif Chowdhury@, Asha Hans, Cynthia Addoquaye Tagoe, \\ Andrew Allan, Winfred Nelson, Amrita Patel, M. Shahjahan Mondal, Mashfiqus Salehin, \\ Ruth M. Quaye and Shouvik Das
}

Department of Sociology, University of Dhaka, Dhaka-1000, Bangladesh; arifchowdhury065@gmail.com (M.A.C.); ashahans10@gmail.com (A.H.); candy_tagoe@yahoo.com (C.A.T.); a.a.allan@dundee.ac.uk (A.A.); winfred.nelson@ndpc.gov.gh (W.N.); amritapatel1965@gmail.com (A.P.); mshahjahanmondal@iwfm.buet.ac.bd (M.S.M.); msalehin1968@gmail.com (M.S.); ruthquay@gmail.com (R.M.Q.); geo.shk@gmail.com (S.D.)

* Correspondence: anwar_sociology@du.ac.bd

Received: 24 December 2018; Accepted: 28 February 2019; Published: 10 April 2019

check for updates

\begin{abstract}
Coastal people, especially those living within deltaic areas, encounter major climatic concerns which affect their livelihoods. To cope with this problem, different types of planned adaptation strategies have been implemented guided by laws, policies and programs. However, these guiding documents sometimes fall short of addressing the needs of climate-affected people, especially in natural resource-dependent societies in Asia and Africa. Based on this premise, this paper sought to evaluate the effectiveness of existing policy documents which affect the lives of people living in one large delta (Ganges-Brahmaputra-Meghna in Bangladesh), two medium-sized deltas (Indian Bengal delta-part of the Ganges-Brahmaputra-Meghna and Mahanadi in India), and a small-sized delta (Volta in Ghana). The study followed a mixed methods research design, which included desktop analyses of policies, laws and programs, a questionnaire survey conducted among individuals who played various roles in the policy and legal development processes at national and local levels and focus group discussions at the community level in the three countries. National laws, policies and programs were assessed in the context of climate change adaptation through three lenses: human rights, natural resource management and disaster response. Findings of this paper reveal that the existing documents have some strengths to promote adaptation, although they have some major limitations that cause concerns among the delta communities.
\end{abstract}

Keywords: climate change; delta; coastal people; governance; policy; livelihood; adaptation; Asia and Africa

\section{Introduction}

Coastal areas have been identified as being vital for human progress, as they offer benefits ranging from social, cultural, economic and ecological to human societies [1]. However, deltaic regions are the most vulnerable type of coastal environments due to the coincidence of vulnerable physical characteristics (i.e., low elevation and high flood probability, significant land erosion and gain, dependence on fluvial inputs of water and sediment, high sensitivity to small environmental changes) and socioeconomic characteristics (i.e., high population densities, high prevalence of poverty, gender inequality and low levels of socioeconomic development). Coastal deltas are thus highly susceptible to the impacts of climate change, as well as human activities [2,3]. These reinforce the intensity and frequency of hazards and disasters (e.g., floods, cyclonic storm surge, saline intrusion and erosion) and bring about substantial changes in coastal ecology and biodiversity, both of which 
impact the livelihoods of individuals and communities [4]. Estimates on the impacts of climate change along coastlines worldwide indicate loss and damage of property amounting to billions of dollars annually, even without the additional socioeconomic losses accrued because of lives lost, injuries, and displacement. It has also been observed that a greater proportion of losses and damages that will result from climate impacts along coastlines will be borne by developing countries due to weak institutions, poorly developed early warning systems, and weak capacities to deal with disasters [5]. This lack of institutional capacity is viewed as one major governance challenge for coping with the climatic concerns.

Apart from the direct loss and damage resulting from disasters, the indirect effects of climate change exacerbate problems such as food insecurity, unemployment and health, as well as migration [6]. All of these issues threaten the livelihoods of people living along the coast and also constitute major national and global challenges. Adaptation has been seen as the best option for developing countries to address the challenges posed by climate change. It entails the use of climate change-oriented development policies and programs across all scales of governance, and especially at the community level, in order to reduce the human and socioeconomic risks and losses resulting from climate change [7-10].Given the weaknesses of general development policies and weak institutional systems, governance frameworks have often been conceptualized as the strengths, weaknesses, and limitations of laws, policies, and programs, which are formulated with a view to promoting better adaptation and securing decent livelihoods in the context of climate change effects [11]. It is important to understand to what extent governance systems can address the challenges faced by delta populations.

The effectiveness of governance approaches in terms of strengths and weaknesses is appraised through different lenses, with three important dimensions being human rights, natural resource management and disaster response. These intersect multiple sectors such as water, agriculture and food, and are frequently influenced by climatic events (e.g., flood, drought, salinity intrusion, river bank erosion and cyclonic storm surge). Human rights dimensions are described as social, cultural, economic and ecological aspects of decent livelihoods in terms of accessing employment, food, education, health care and housing in the delta regions. Human rights need to be recognized in climate change adaptation policies and programs in order to protect people's livelihoods, which are linked to the impacts of climatic and environmental stresses, such as crop loss, unemployment, starvation and displacement. Human rights concerns are often multi-dimensional, leading to distributional outcomes for different groups of people, e.g., farmers, fishermen, boatmen, women, aged and disabled. Understanding people's vulnerabilities to climate change is central to the effectiveness of household adaptation, which can be strengthened via adopting a human rights approach. Resilient and robust options for natural resource management is a key pathway for climate change adaptation. As there are differences in histories and cultures across geographical regions in terms of the use and maintenance of natural resources, governance challenges include coordination between top-down and bottom-up approaches and the integration of natural-cultural heritage.

The main focus of this paper is to evaluate the effectiveness of existing policy frameworks affecting the lives of people living in coastal deltaic regions. We researched four delta study sites in three countries: one large delta (Ganges-Brahmaputra-Meghna delta in Bangladesh), two medium-sized deltas (Indian Bengal delta- Indian part of the Ganges-Brahmaputra-Meghna delta, and Mahanadi delta in India) and a small-sized delta (Volta delta in Ghana). We assessed national policies and legal frameworks in the context of climate change adaptation through three lenses: human rights, natural resource management and disaster response, wherein we tried to identify the strengths and gaps, as well as the opportunities for strengthening governance arrangements attuned to the approaches with human rights, natural resource management and disaster response. 


\section{Governance Approach to Climate Change: Focus on Human Right, Natural Resource Management and Disaster Response}

Examination of governance that is relevant to climate change in the context of adaptation demands assessment across scales, from local and national to the international level. Sachs (2008:333) argues that increased global warming means greater policy challenges for addressing the adaptation concerns according to the International Covenant on Economic, Social and Cultural Rights [6]. This includes, among other things, requirements on standards of living with adequate food, clothing and housing under Art. 11 and health under Art. 12. In this context, policies need to recognize the cultural, social and ecological effects of climate change on delta regions. In the same vein, Adger et al. (2012) focus on cultural dimensions of climate change which describe material and non-material aspects of identity, community cohesion and place attachment [12]. For example, physical impacts like droughts cause reductions in crop production, wild fish and vegetation, which create downward social mobility. These socio-ecological connections are responsible for transforming social structures as a significant number of people encounter forced migration and demographic shifts [13]. Knox (2009) describes these socioeconomic vulnerabilities through a human rights approach, based on the contribution of the Office of the UN High Commission for Human Rights (OHCHR), conceptualizing the adverse effects of climate change and state responsibility [14]. The areas and populations which are most vulnerable to climate change merit special attention in terms of adaptation activities, which need to address the disastrous negative impacts of climate change on their quality of life and the critical issue of ensuring people's access to water and land over longer periods. Kravchenko (2008) describes human rights as the central thematic point of enforcing rights in the law and policy of a government [15].

Human rights are thus described as the social, cultural, economic and ecological aspects of maintaining a decent standard of living, i.e., in securing local poor people's rights to employment, food, education, health care and housing in the delta regions (e.g., the three study areas considered in the current paper: Bangladesh, India and Ghana). The major governance challenges for this human rights protection in coastal areas are reinforced by unfavorable physical characteristics such as low elevations and high probabilities of environmental hazards, and socioeconomic characteristics such as high population densities, poverty and gender inequality. The increasing climatic concerns associated with floods, cyclonic storm surges, saline intrusion and erosion, and disruption in coastal ecology and biodiversity cause major human rights concerns across different livelihood groups, including the marginalized. These concerns originate from crop loss, food insecurity, unemployment, disease burden, forced migration, illiteracy and malnutrition. Climate change policies and programs need to foster coordination between physical and socioeconomic aspects of climate change effects, i.e., to ensure access to freshwater, land, employment, education and housing by overcoming exclusion, inequality, exploitation and vulnerability.

In sum, adopting a human rights approach helps us to better understand which people are vulnerable and are at climatic risk. Natural resource management needs to be attuned to this human rights approach; the sustainable and equitable use of natural resources will in turn be helpful to effect human rights protection of the marginalized people in the coastal regions. Key elements of vulnerability encompass exposure, system sensitivity and adaptive capacity [16]. Vulnerability varies across different social-ecological systems, depending on how local communities, families and individuals are connected to local agricultural and natural resources. Natural resource management is at the core of climate change adaptation. Climate change policies and programs need to appreciate that protecting the integrity and diversity of nature, and ensuring equitable and ecologically sustainable use of natural resources, are vital to reducing the vulnerability of human systems to climate-related hazards. It is important to realize that there are differences of history, culture and community in the different regions in terms of dependence on and use of natural resources [17]. As emphasized by Urwin and Jordan (2008), ensuring sustainable natural resource management requires coordination between top-down and bottom-up approaches related to sectors such as agriculture, fisheries and other ecological resources [11]. This coordination can be helpful in reviewing existing policies, programs and 
laws to support local adaptation. Griffiths et al. (2007), along the same line, describe this approach with four components of institutional governance systems: state, market, corporation and collaboration, interactions between which can establish institutional frameworks, policies and capabilities that innovate new adaptation approaches [18]. Camacho (2009) argues that proper legislation and agencies can promote these policies to reduce the adverse effects and ensure livelihood security [19].

Governance arrangements for climate change need to facilitate flexible policy formulation and execution aiming at sustainability and socialecological system resilience. Building adaptive capacities for local coastal people to cope with adverse effects is one of the major components of social resilience development based on social institutions [20]. Based on work by the IPCC (1990:103), Boncour and Burson (2009) point out that no single policy can adequately address climate change by itself, as the impacts of climate change are widely felt across multiple sectors such as water, agriculture and food, frequently shaped by environmental events like flood, drought, salinity intrusion and erosion [21,22].

\section{Methods}

This paper draws on data collected as part of the 'DEltas, vulnerability, Climate Change: Migration and Adaptation (DECCMA)' Project (www.deccma.com), with study sites located in Bangladesh, Ghana and India (see Figure 1 for the study areas in the three countries).The Volta in Ghana is a small delta, covering a total area of 4562 sq.km in the Keta basin, which is within the lower part of the Volta River basin, a transnational catchment shared by six countries. The delta has a diverse economy including agriculture, fisheries, salt harvesting and sand mining as well as tourism, with the agricultural and fishing sectors providing significant employment. Many contemporary problems are recognized in the Volta delta, especially the erosion and flooding of the open coast fringe, such as at the town of Keta. Flooding was a bigger problem in earlier times; however, since the construction of dams, starting with the Akosombo Dam in 1964, flow from upstream has been controlled, but sediment supply has been considerably reduced, leading to significant shoreline recession [23].

The Mahanadi in India is a medium-sized delta, covering an area of nearly 13,000 sq.km and drained by the network of three major rivers: Mahanadi, Brahmhani and Baitarini into the Bay of Bengal. Chilika Lake, the largest coastal lagoon in Asia is situated in the far south of the delta. On one hand, it is one of the most populated river deltas of India, supported by very fertile agricultural lands in the upper part of the delta, while on the other hand, the delta is vulnerable to tropical cyclones, floods and droughts [24]. Floods have been a perennial problem, which continuously bring about changes in land use patterns [25]. Coastal erosion is a threat to the historically and culturally important city of Puri in the delta.

The Ganges-Brahamaputra-Meghna delta is on the north of the Bay of Bengal, spanning the international boundary between India and Bangladesh. The major part of the delta lies within Bangladesh, spanning over 19 coastal districts. The Indian part of the delta (Indian Bengal Delta- IBD) covers 14,054 sq.km over two administrative districts (North 24 and South 24 Parganas). The delta is characterized by a number of livelihood opportunities resulting from high population density, but faces a number of biophysical and socioeconomic challenges generated by a number of hazards and disasters (flooding, erosion, cyclones, salinization, water logging etc.). People of this delta are mainly dependent on the agricultural sector, while people living in the coastal belt are dependent on traditional rice cultivation as well as riverine and marine fishing. The delta supports a diversity of ecosystem services, including the Sundarbans, the world's largest mangrove forest, covering 10,000 sq.km and shared between Bangladesh ( 60 percent) and India (40 percent). The Sundarbans provide a wide range of livelihoods to the people living on its periphery [2].

The study followed a mixed methods research design, which included desktop analysis of policies, a questionnaire survey conducted among national and local level stakeholders and focus group discussions (FGDs) at the community level. Additionally, relevant data were used from a questionnaire survey conducted in all three deltas. Table 1 summarizes the methods used in the study for generating necessary data and information. 


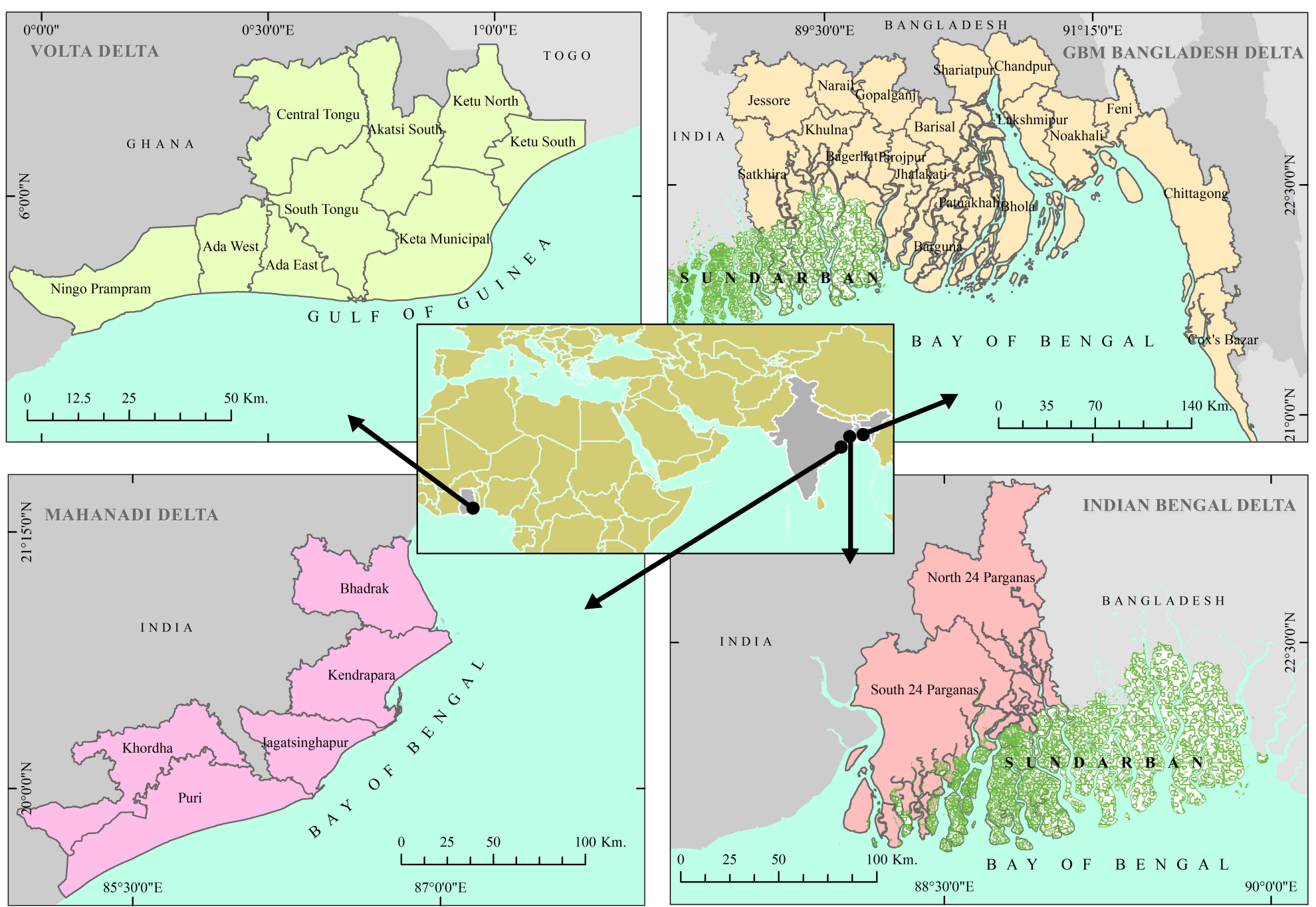

Figure 1. DECCMA Study Area in Coastal Africa and Asia/Bangladesh, Ghana and India. 
Table 1. Methods Used in Data Collection.

\begin{tabular}{|c|c|c|c|c|}
\hline \multirow[t]{3}{*}{ Methods Used } & \multicolumn{4}{|c|}{ Countries } \\
\hline & \multirow[t]{2}{*}{ Bangladesh } & \multirow[t]{2}{*}{ Ghana } & \multicolumn{2}{|c|}{ India } \\
\hline & & & IBD & MD \\
\hline c. Questionnaire survey & 1384 (Sample size) & 1364 (Sample size) & 1315 (Sample size) & 1414 (Sample size) \\
\hline d. Focus Group Discussion (FGD) & $\begin{array}{l}13 \text { FGDs (conducted prior to } \\
\text { questionnaire survey) }\end{array}$ & $\begin{array}{l}\text { About } 40 \text { people } \\
\text { divided into five } \\
\text { groups based on } \\
\text { their interests }\end{array}$ & \multicolumn{2}{|c|}{$\begin{array}{l}13 \text { FGDs (conducted prior to } \\
\text { questionnaire survey) }\end{array}$} \\
\hline
\end{tabular}

Taking into cognizance the multi-scalar and multi-sectoral dimensions of governance mechanisms, local and national governance contexts (laws, policies and institutions) were examined to understand the existing and potential capacity of the governance systems to address the challenges faced by the delta populations. A large number of relevant laws, legislations, policies and plans were thoroughly analyzed, guided by a comprehensive set of governance questions addressed to sectors that are potentially relevant to climate change adaptation: Human rights related to adaptation; Natural Resource Management and Ecosystem Protection; Disaster Response; and Climate Change Adaptation. A questionnaire survey, hereinafter termed 'Barrier to Policy Implementation (BPI) Survey', was conducted in all three deltas with a range of national level (represented by different government ministries, departments and agencies) and local (district) level (represented by local governmental and non-governmental institutions) stakeholders with a view to deriving stakeholders' perceptions on the effectiveness of policies in addressing adaptation issues and/or options and the barriers to implementation of policies [26].

In addition to this survey and content analysis, this paper draws on information from Focus Group Discussions (FGDs) with the local people in different climate hotspots within the study areas, and a number of national or state level and district level (in climate hotspots) workshops, conducted in order to derive stakeholder opinions on different dimensions of governance, climate change adaptation and migration. The views of households on adaptation to climate change impacts are also incorporated in this paper through the use of results from the household surveys conducted in the study areas at sample climate hotspots ranging from low to very high hazard in 2016 and 2017.

\section{Results and Discussion}

\subsection{Policies Reviewed}

In Bangladesh, Ghana and India, the respondents involved in the barriers to policy implementation survey reviewed a wide range of policies which, as per their estimation, may address challenges that arise within deltas due to climate change. It was observed that, in all the three countries, respondents mostly reviewed policy documents that were directly addressing climate change. For instance, most respondents in Bangladesh reviewed the Bangladesh Climate Change Strategies and Action Plan; in Ghana, the single most reviewed policy was the National Climate Change Policy. In the Indian Bengal Delta (IBD) of India, it was the West Bengal State Action Plan on Climate Change (2012) which emerged as the most well-known document among the participants of the survey and it was considered as a good action plan which could help people to better adapt [27]. In the Mahanadi delta of India, the Odisha Disaster Management policy, Odisha State Climate Change Action Plan and Odisha 
Agricultural policy were considered as the most important policies in the context of climate change. Other policies which respondents reviewed focused on sectors that are of utmost importance to deltaic and coastal residents. These included policies directed at agriculture, development, coastal protection and buffer zone protection as well as gender and social protection programs.

Clearly, all three countries involved in the study were perceived as having substantial policies which are directed towards climate change adaptation and mitigation. It was also observed from the data that respondents tended to review policies which were linked to their concerned sectors. However, as climate change is a cross-cutting issue, respondents from different socioeconomic and professional backgrounds reviewed the policies based on their own relationships to issues like human rights protection or natural resource management.

\subsection{Human Rights Approach to Climate Change Adaptation}

Our examination of laws, policies and programs revealed that policies in the three countries contained what is required to ensure protection of the general rights of individuals. In Bangladesh and Ghana, human rights have their foundations in the countries' constitutions; however, there are no specific laws on the rights of individuals affected by the impacts of climate change. For example, the constitutions of the three countries protect the right of a person in relation to freedom of movement, e.g., to seek safety in another part of the country, or leave the country and seek asylum in another country. But there is no legal basis to protect the properties or possessions left behind by the internally-displaced people after a disaster and to create conditions which would allow them to return voluntarily to their origin. There are no entitlements to accessing social and/or psychological services either.

The governments in the study countries provide more focus on social service programs intended to help local people to cope with climate change effects. There were laws and policies that focused on social protection programs like old age allowances, medical benefits and recreational facilities for the marginalized groups like aged, destitute, disadvantaged, persons with disability, orphaned and widows or deserted women of local communities. Participants in the stakeholder workshops, organized at the state and district levels both in Indian Bengal Delta and Mahanadi Delta of India, stressed that there is a need for effective interaction between the policy makers and researchers/academics with the village community, which can help to clarify the vulnerability of the people living in the deltas.

According to DECCMA household survey data (2017) in Bangladesh, 34 percent of the total respondents invest in education as an adaptation option. Furthermore, the Char Development and Settlement Project (CDSP) is also working to provide shelters for displaced people. In Bangladesh, while there are specific laws granting land ownership to resettled people, this was not the case in Ghana, as the constitution already granted people the opportunity to move within and outside the territories of the nation as long as they do not settle on vested lands such as those belonging to the military. Results of the survey indicated that the majority of respondent households in Bangladesh, Ghana and India owned their own homesteads, with ownership being the highest in the Indian deltas (see Table 2). This is a reflection of the relatively high level of human rights protection. Coverage of drinking water is reasonably high in all the deltas via different technologies, predominantly piped water distribution system and tube-wells. However, these numbers do not reveal different dimensions of drinking water security, including safety, access and affordability. Sanitation facilities (including flush toilets and pit latrines) are available to a higher proportion of the population in the GBM delta, followed by the Indian Bengal delta, while the proportion is lower in the Mahanadi and Volta deltas. As climate change poses a major threat to safe drinking water and sanitation, climate change focused development policies and programs are becoming imperative. 
Table 2. Household Characteristics in the Three Deltas.

\begin{tabular}{|c|c|c|c|c|}
\hline \multirow{2}{*}{ Issue } & \multirow{2}{*}{ Bangladesh (\%) } & \multirow{2}{*}{ Ghana (\%) } & \multicolumn{2}{|c|}{ India } \\
\hline & & & IBD (\%) & MD (\%) \\
\hline \multicolumn{5}{|l|}{ Sex of respondents } \\
\hline - $\quad$ Male & 52.2 & 55 & 85.2 & 86.6 \\
\hline - $\quad$ Female & 47.8 & 45 & 14.8 & 13.4 \\
\hline \multicolumn{5}{|l|}{ Ownership of homesteads } \\
\hline - Own homestead & 89.2 & 85 & 95.1 & 96.0 \\
\hline - $\quad$ Mortgaged home & 0 & 0 & 0.1 & 0.0 \\
\hline - $\quad$ Renting & 3.9 & 13 & 3.1 & 1.2 \\
\hline - $\quad$ Squatting & 6.9 & 2 & 1.7 & 2.8 \\
\hline \multicolumn{5}{|l|}{ Source of drinking water } \\
\hline - Piped water at home & 5.8 & 9 & 23.2 & 15.4 \\
\hline - Stand pipe & 0.4 & 46 & 9.0 & 0.1 \\
\hline - $\quad$ Tube-well & 86.9 & 8 & 66.9 & 76.6 \\
\hline - $\quad$ Dug well & 1.5 & 13 & 0.2 & 7.3 \\
\hline - $\quad$ Spring & 0 & 0 & 0.0 & 0.0 \\
\hline - $\quad$ Rain water & 0.4 & 3 & 0.0 & 0.0 \\
\hline - $\quad$ Surface water & 5.0 & 7 & 0.0 & 0.6 \\
\hline - $\quad$ Others & 0 & 14 & 0.7 & 0.0 \\
\hline \multicolumn{5}{|c|}{ Kind of latrine used by household } \\
\hline - Flush & 4.6 & 8 & 25.8 & 29.2 \\
\hline - $\quad$ Pit & 90.3 & 30 & 57.7 & 8.0 \\
\hline - $\quad$ No facility & 4.6 & 40 & 16.2 & 62.7 \\
\hline - Other & 0.4 & 22 & 0.3 & 0.1 \\
\hline Total (n) & 1384 & 1364 & 1315 & 1414 \\
\hline
\end{tabular}

Source: DECCMA Household Survey in sampled climate hotspots (2017).

Despite the efforts put in place by the governments of the three countries, it was clear from survey results and policy content analysis that adaptation policies and programs fall short of recognizing the normative criteria of human rights in the context of climate change adaptation. This limitation has more implications for marginalized groups of people. The household survey revealed that 32 percent of the total households in Bangladesh and 34 percent in Ghana eat one meal a day or less at varying frequencies in the year because of their economic vulnerability. In India, 46 percent of the female headed households in the Indian Bengal Delta and about 50 percent in the Mahanadi Delta, eat less than one meal a day in varying frequencies (Table 3). The analysis further shows that in all three countries-Bangladesh, Ghana and India-female adults are more likely to go hungry than male adults or children. This gender discrimination presents a major governance challenge for the policies and programs in the delta countries.

Table 3. Household Dietary and Migration Decisions due to Climate and Economic Challenges.

\begin{tabular}{|c|c|c|c|c|c|c|}
\hline \multirow[b]{2}{*}{$\begin{array}{l}\text { Country } \\
\text { Household } \\
\text { Head (HHh) }\end{array}$} & \multicolumn{3}{|c|}{ Issue } & \multirow[b]{2}{*}{$\begin{array}{l}\text { Female Adult Is } \\
\text { More Likely to Go } \\
\text { without Food }\end{array}$} & \multirow[b]{2}{*}{$\begin{array}{c}\text { Migrant } \\
\text { Household }\end{array}$} & \multirow[t]{2}{*}{ Total } \\
\hline & $\begin{array}{l}\text { Eat Less Than One } \\
\text { Meal a Day } \\
\text { Frequently }\end{array}$ & $\begin{array}{l}\text { Eat Less Than One } \\
\text { Meal a Day a Few } \\
\text { Days in a Year }\end{array}$ & $\begin{array}{l}\text { Eat More } \\
\text { Than One } \\
\text { Meal a Day }\end{array}$ & & & \\
\hline \multicolumn{7}{|c|}{ Bangladesh } \\
\hline Male HHh & 4.2 & 27.4 & 68.4 & 22 & 27.5 & 1101 \\
\hline Female HHh & 7.2 & 28.1 & 64.8 & 82 & 56.83 & 278 \\
\hline \multicolumn{7}{|c|}{ Ghana } \\
\hline Male HHh & 4 & 30 & 66 & 29 & 43 & 806 \\
\hline Female HHh & 7 & 29 & 65 & 87 & 57 & 555 \\
\hline \multicolumn{7}{|c|}{ India (IBD) ${ }^{1}$} \\
\hline Male HHh & 9.1 & 29.2 & 61.7 & 98.6 & 16.3 & 1120 \\
\hline Female HHh & 13.9 & 32.0 & 54.1 & 100.0 & 27.7 & 195 \\
\hline \multicolumn{7}{|c|}{ India (MD) ${ }^{2}$} \\
\hline Male HHh & 10.3 & 31.8 & 57.9 & 98.2 & 18.6 & 1225 \\
\hline Female HHh & 18.5 & 31.2 & 50.3 & 100.0 & 43.4 & 189 \\
\hline
\end{tabular}

Source: DECCMA Household Survey in sampled climate hotspots (2017). ${ }^{1}$ The percentages are excluding the 'don't know option'; ${ }^{2}$ The percentages are excluding the 'don't know option'. 
More than half of the survey respondents in Bangladesh and Ghana and 43 percent of the respondents in India were not willing to migrate or were hesitant. A sense of insecurity often plays a role in migration decisions, resulting from a fear in migrating alone and uncertainties around care and protection for the families left behind. FGD participants in Bangladesh observed that there are no mechanisms, laws or policy support for displaced people to know the fate of their missing relatives. In Ghana, where a similar situation exists in the laws and policies, very few respondents (15 percent) expressed these fears and insecurities as issues that affected their migration decisions.

The governments of the delta countries have major policy efforts on the resettlement of the climate victims, but they are faced with some governance challenges. There are some instances of planned migration and relocation in India. The Government of West Bengal took measures to resettle the people from the submerged villages of Ghoramara and two islands of Lohachhara and Suparibhanga in the Indian Bengal Delta to the neighboring island of Sagar-an example of "Planned Migration" [28]. In the area of Mahanadi Delta, resettlement is being carried out by the Department of Relief and Rehabilitation, Government of Odisha from the villages of Satabhaya and Kanhupur of Satabhaya Gram Panchayat (GP) in Kendrapara district, to Bagapatia under Rajnagar Tehsil of the same district due to severe coastal erosion in the area. A total of 571 families are being resettled [28].

In Ghana, the government had plans to resettle people within the Volta Delta, specifically Keta, in the early 1900s, when it was discovered that the area was below sea level. However, the people of the community rejected resettlement plans [29]. It was not until 1999 that the government succeeded in convincing the people to resettle. This was when communities were affected by both sea level rise and erosion. The new resettlement plan sought to resettle the people on lands which were originally settled but which have since been lost to the sea. The resettlement program, which is an aspect of the Keta Sea Defence Project, started in 1999, had the aim of resettling a total of 1200 households affected by sea level rise [30,31]. Under the resettlement program, the government built houses and also compensated displaced populations for the loss of crops, shrines and stool.

There is a Resettlement Policy (2015) in Bangladesh; however, resettlements have yet to achieve their desired goals [32]. A field investigation revealed that resettled people are not fully satisfied with infrastructure facilities and are particularly unsatisfied with the level of government support for livelihood transition. Successful resettlements require the relocation to a community in which work can be secured (either through employment or developing enterprises) and in which there are better opportunities for social services. This requires infrastructural initiatives (especially housing) to be in line with planned intervention, such as the "Cluster Village" model; economic, social and cultural integration of the resettlers given priority in long-term resettlement planning decisions; and more efficient communication and coordination between the government and development partners.

Climatic victims encounter human rights uncertainties, step into forced migration and look for any form (legal or illegal) of employment opportunities. This climate-induced migration and employment search are major concerns in Bangladesh. Interactions in the state and district level stakeholder workshops in the Mahanadi and Indian Bengal Delta revealed that the outmigration for employment is the current trend; though earlier it primarily concerned adult males, presently, there are instances of adult women migrating out of the state (Odisha) after being skilled for jobs. Again, the most important barriers to migration in the Mahanadi delta and the Indian Bengal delta are the inability to attend to family commitments at home and the lack of resources. In Bangladesh, participants of the FGDs were of the view that the government needs to establish specific laws for the properties of displaced people. Additionally, the district-level workshop and FGDs highlighted that policy documents do not secure one's right to employment. Due to increasing intensity and frequency of climatic concerns, the rate of unemployment and the number of internally-displaced persons are increasing, especially in Bangladesh and India. 


\subsection{Natural Resource Management for Climate Change Adaptation}

Due to economic hardships caused by climatic concerns, people may tend to abuse the environment in order to secure their livelihood. It is for this purpose that different laws and policies are formulated and implemented to protect the ecosystem. In Bangladesh and Ghana, it was observed that there were several legal provisions which seek to ensure both environmental protection and coastal conservation for the protection of the lives of coastal people. In Ghana, there were institutions such as the Ministry of Lands and Natural Resources, Environment and Fisheries which had offices at the local level and dealt with the aspects of the environment that fall within their purview. In Bangladesh, participants spoke about legal instruments and policy documents that promote natural resource management. Some of the documents identified include the Bangladesh Environment Conservation Act (1995), which enables legal mandates to conduct Environmental Impact Assessment (EIA) before establishing any development project to avoid any potential harms related to local poor people and environment, and the Wildlife Preservation Order (1973), which is practiced together with the conservation approach to ensure that areas demarcated as protected areas are observed and used as such [33,34].

Participants in the FGDs also intimated that the Bangladesh Department of Forest (DoF) under the financial assistance of World Bank has adopted a project, Strengthening Regional Cooperation for Wildlife Protection, to protect biodiversity and wildlife. As part of this protection, the government in Bangladesh imposes restrictions on cutting all types of trees until 2022. In Ghana, participants in the FGDs mentioned that the Forest Act, Fisheries Act and Wildlife Act contained legal provisions which are intended to protect the natural ecosystem. They further identified that Ghana's status as a signatory to the CITES Convention ensures that endangered plant and animal species are protected and given time to be restored into the ecosystem.

A policy review revealed that in India, prior to the National Action Plan on Climate Change of 2008, the National Environment Policy (NEP) of 2006 was the first policy that made a significant impact by citing the key environmental challenges $[35,36]$. The Coastal Zone Regulation notification and the Agriculture Vision are also vital instruments that elaborate on natural resource management for climate change adaptation. The Odisha State Climate Action Plan (2010) aims to achieve efficient management of natural resources by enhancing capacity building, implementing integrated approaches, investing in research and development, and strengthening institutional mechanisms [37]. In the case of West Bengal, climate change adaptation strategies are identified based on the concerns on water resources, agriculture (covering crops, horticulture, livestock and fisheries), biodiversity and forests, human health, energy efficiency and renewable energy, habitats, and special regions of Darjeeling Himalayan and the Sundarbans, according to West Bengal State Action Plan on Climate Change (2012) [27]. In addition, the FGD respondents identified the Mahatma Gandhi National Rural Employment Guarantee Act (2005) along with the State Agriculture Plan for West Bengal (2009) as the key policies relevant for sustainable adaptation $[38,39]$.

Other policies which were identified in the national- and district-level (barriers to policy implementation) surveys of Bangladesh, Ghana and India include those related to the environment such as water and buffer zones policies, land use and forest. These policies tend to ensure sustainable use of land and natural resources in order to protect both the natural ecosystem and humans from floods, droughts and other climatic impacts that may result from unsustainable use of land.

In Ghana, 50 percent of respondents held the view that agricultural diversification had been addressed by policies (Table 4). The respondents, however, expressed the view that the implementation of Ghanaian policies has been weak in addressing the ability of individuals to leave agriculture for other areas of employment; with only one-fifth of respondents ( 20 percent) being of a contrary view (Table 4). 
Table 4. Respondents' Views on Issues Addressed by the Policies in the Three Countries.

\begin{tabular}{|c|c|c|c|c|}
\hline \multirow{3}{*}{ Issues Addressed by Policies } & \multirow{2}{*}{ Bangladesh } & \multirow{2}{*}{ Ghana } & \multicolumn{2}{|c|}{ India } \\
\hline & & & IBD & MD \\
\hline & Agree/Fully Agree (\%) & Agree/Fully Agree (\%) & Agree/Fully Agree (\%) & Agree/Fully Agree (\%) \\
\hline Easy recovery from natural disasters & 83 & 33 & 0 & 21 \\
\hline Better preparedness for natural hazards & 66 & 47 & 8 & 29 \\
\hline Social services delivery improved & 79 & 67 & 14 & 25 \\
\hline More and better information collection & 61 & 44 & 0 & 25 \\
\hline Access to early warning systems & 74 & 40 & 0 & 35 \\
\hline New agricultural research conducted & 95 & 60 & 14 & 18 \\
\hline Institutional capacity strengthened & 74 & 20 & 20 & 29 \\
\hline Women are empowered & 89 & 63 & 23 & 13 \\
\hline Climate proof infrastructure & 64 & 27 & 7 & 9 \\
\hline $\begin{array}{l}\text { Resilience planning improved in rural and } \\
\text { urban areas }\end{array}$ & 52 & 60 & 0 & 17 \\
\hline Better opportunity to diversify in agriculture & 84 & 50 & 27 & 17 \\
\hline Better opportunity to leave agriculture & 58 & 20 & 0 & 17 \\
\hline Marine or coastal management improved & 65 & 20 & 0 & 23 \\
\hline Improved water resources management & 74 & 67 & 7 & 21 \\
\hline Total Respondents & $47^{1}$ & $18^{2}$ & $19^{3}$ & $32^{4}$ \\
\hline
\end{tabular}

Source: DECCMA Barrier to Policy Implementation (BPI) Survey (2017). ${ }^{1}$ Respondents' views on the issues addressed from national level data; ${ }^{2}$ Respondents' views from the national level; ${ }^{3}$ Respondents views from the state level respondents survey of Barriers to policy implementation; ${ }^{4}$ Respondents views from the state level respondents survey of Barriers to policy implementation.

The policies that facilitate better opportunities to diversify in agriculture were suggested by 27 and 17 percent of the state level respondents in the Indian Bengal and Mahanadi Delta in India, respectively. Again, 35 percent of the respondents in MD have access to early warning systems. The empowerment of women and improved water resource management were some of the other issues in the state of West Bengal and Odisha that the respondents said were being addressed by the policies. With regards to water resource management, respondents in Bangladesh and Ghana held varying views on the effectiveness of policies in dealing with this issue among coastal residents. In Bangladesh, it was identified that improved water resources management contributed to 74 percent of all adaptation while in Ghana, more than half of respondents who participated in the Survey (67 percent) agreed/fully agreed that water resources were, to varying extents, satisfactory. Coastal and marine management was described by the respondents as having been addressed to some extent, but that it deserves more attention, with 20 percent of the stakeholders in Ghana and 23 percent of the respondents in the Mahanadi Delta agreeing/fully agreeing with the implemented policies (Table 4). Strengthening of institutional capacities, improved social service delivery and new agricultural research are issues which are viewed as being addressed in varying degrees by the policies in Bangladesh, Ghana and India.

One of the emerging research agendas is indigenous agricultural practices to cope with climate change effects. Practicing sustainable agriculture, besides ensuring food security for the community, is anticipated in response to the changing forms of soil, water and temperature. The West Bengal Climate Change Action Plan (2012) suggests the adoption of indigenous or traditional rice varieties which are tolerant to salinity and flood, to fight the adverse impacts of climate change [27]. The age-old traditional farmer's variety of seeds of agricultural crops have been shown to be more climate-change resilient i.e., less affected during floods, saline contaminations and droughts, etc., and hence, switching back and/or opting for traditional indigenous seeds would ensure secured food supplies and help build community resilience against future climate change-induced impacts. At the same time, introducing integrated farming systems with the combination of crops, fisheries and livestock, the document pointed out, would ensure self-sustainability and livelihood alternatives in India. The recognition and incorporation of this local agricultural knowledge in climate change adaptation policies and programs is a governance challenge. The farmers or proper representatives who are repositories of this knowledge need to be included in policy making and execution processes. In this context, it is important to coordinate between top-down and bottom-up approaches to ensure sustainable natural resource management.

In Bangladesh, the FGD participants identified some major measures like capacity building for integrating climate change in planning and land-water zoning for water management institutions, 
exploring options for insurance companies to cope with climatic concerns. The district-level workshop identified inadequacies in the research on sustainable adaptation, accountability and transparency, participation and effectiveness of local resource management committees. The national level workshop in Bangladesh reveals that most relevant legislation, e.g., Water Act 2013 and CCGAP 2009, did not recognize cultural and historical factors in reducing the effects of climatic concerns [40,41]. According to DECCMA household survey data, 58 percent of the total respondents did not have any agricultural land who have the different types of livelihood practices that need to be addressed properly in the planned adaptation. This differential access to land and the relevant cultural practices need to be described with the government approach.

The national level workshop data informs us that the government in Bangladesh needs to focus more on policy and legal aspects of international river management to ensure sustainable water flow of the Ganges-Brahmaputra-Meghna (GBM) Basin in order to promote climate change adaptation. Currently, no international river basin agreement is in place to ensure a holistic approach to manage the GBM that encompasses the entire catchment area from the Himalaya Mountains to the Bay of Bengal. Lack of cooperation and constructive engagement among the different GBM countries create multiple challenges for water management downstream. On the other hand, in Ghana, there is an international Volta River Basin Management Agreement between the six countries through which the Volta River flows, namely Ghana, Burkina Faso, Cote d'Ivoire, Mali, Togo and Benin. The agreement which was signed in 2006 establishes the Volta Basin Authority in Burkina Faso to oversee that all member countries uphold the provisions in the agreement [42]. As with the GBM, no basin-wide agreement exists across the relevant Indian states for the management and regulation of the Mahanadi River.

\subsection{Climate Change, Adaptation, Migration and Governance Intersectionality}

As reviewed in the literature, there is a connection between climate change adaptation and migration. Results indicate that Ghana does not have any clear policies and laws on internally-displaced people and internal migration due to climate change or environmental causes. It was identified from the FGDs that the laws only make provisions for the relocation of people whose lands have been earmarked for redevelopment for public purposes. Participants in this case cited several examples where this law had not been adequately followed to protect the rights and interests of the climate-affected people.

Furthermore, in Bangladesh, it was identified that there is a National Plan for Disaster Management (2010) which provides guidelines for social protection for the different groups of marginalized people like women, children, elderly and the disabled [43]. For example, the Land Holding Limitation Order (1972) protects the rights to land for these groups of people [44]. Additionally, the Standing Orders on Disasters (SoD) (2010) emphasize the legal framework for disaster risk reduction and emergency response in terms of compulsory obligations and responsibilities at all levels of the Disaster Management Committees (DMC) [45].

However, the governance challenges for the climate change adaptation policies, according to the FGDs, are that cultural dimensions did not get proper recognition in the current disaster response policies in Bangladesh. The needs of women were not considered during the setting up of cyclone shelters in order to provide them with bathrooms and bedrooms separate from the men. Moreover, the lack of understanding about socioeconomic and cultural norms in the policy documents causes adaptation concerns. For example, local people in the coastal area in Bangladesh have, for generations, practiced their cultivation and ownership of resources through cooperation among households and social networks within and beyond the local groups, but national policy does not adequately incorporate these considerations into climate change adaptation.

In India, the aspects of migration linked to climate change and extreme events are not appropriately articulated. Seasonal migration is a standard practice, largely due to lack of opportunities in both the Indian Bengal Delta and Mahanadi Delta during dry seasons, (especially with farming being dependent on monsoon rain), but the rate of migration from the region increased, for example, after Cyclone Aila in 2009. 
However, Mahanadi Delta has seen migration as one of the forms of adaptation in addition to a number of other measures like double seeding, irrigation, changing crop practices (e.g., using different varieties of seeds, crop diversification and different planting dates) and shifting of land use pattern. But the kind of adaptation activities undertaken by households is dependent on socioeconomic, demographic and institutional factors. It was seen that education and large family size had a positive influence on migration, as did land size and wealth index. The ownership of land was found to influence all the adaptation choices positively and significantly except migration; the landless people being the worst victims, and therefore, the most likely to migrate first in adverse conditions in India [46,47].

In Bangladesh, another governance issue that was discussed and reviewed is climatic data management as the ability of individuals to respond to climate hazards depends on the amount of information available to them. It was observed, however, that due to a lack of proper community engagement along with lack of proper operating mechanism, the policy documents fail to provide locality-specific information related to disaster events. The FGD data indicated that local farmers wanted to know the levels of climate variability, which can be provided with weather forecasts, to decide on the following year's cropping practices. Only the proper governance approach can reduce the gap between government and delta people in promoting climate change adaptation related to the different issues like climatic data sharing, disaster response and natural resource management for the human rights protection

\section{Conclusions}

The analysis presented in the preceding section clearly reveals that economic, social and cultural integration is a prerequisite for climate change adaptations to be fully effective. In order for this to materialize, it is necessary to make efforts in coordinating top-down and bottom up approaches, via community participation. Currently, community participation lacks adequate attention in the context of environmental conservation and biodiversity protection, although it is one of the major prerequisites for natural resource management. Despite women's representation in the implementation of disaster policies, the decision-making process does not include women. Climate change is a critical issue in the present world and particularly in the three climate vulnerable countries: Bangladesh, Ghana and India. To cope with its effects, it is important to promote proper governance with linkages to public and private actors and the three thematic points of human rights, natural resource management and disaster response. It has been observed that all three countries have noteworthy policies which are aimed at climate change adaptation and mitigation. As climate change is a cross-cutting issue, the protection of bio-diversity needs governments to further initiate different adaptation measures which are holistic in nature and have effective participation of local communities.

Human rights are socioeconomic rights, and they need to be recognized in climate change adaptation policies and programs to protect the livelihoods of delta people in Bangladesh, Ghana and India. All of the policies in these three countries sought to ensure socioeconomic rights of individuals and communities. This human rights dimension is recognized in the constitution in Bangladesh and Ghana. Some policies and programs describe social protection programs like old age allowances or medical benefits for marginalized groups of people like women, aged or disabled people. The planned adaptation performed an important role in the resettlement process in the Indian Deltas. For example, displaced people from two villages in IBD-India and one village in MD-India were successfully resettled. In Bangladesh, specific laws (e.g., the Resettlement Policy) protect land ownership for the resettled people. However, a lack of adequate government support for livelihood transition and better opportunities for social services is often an obstacle to the optimum success of the resettlement process. In India, the strengthening of institutional capacities, improved social service delivery and new agricultural research were the issues that were perceived to be the major governance challenges. The extent of policy implementation is often inadequate in addressing the current level of adaptation concerns over the delta people in the three countries. Very few social programs in Bangladesh are specifically designed taking into consideration the effects of climate change. 
In all the deltas studied, the governments failed to adequately recognize the linkage between human rights and climate change adaptation in their own policies and programs. In Ghana, no specific laws exist to protect the land ownership of the displaced people during their resettlement process. In Bangladesh, no laws have been established for displaced people regarding getting connected with their relatives. In India, climate-affected people are hesitant to migrate due to insecurity in the destination areas or family members' insecurity in the area of origin. The delta people in Ghana also encounter this type of concern. Despite this, some delta people migrate for employment opportunities, as unemployment rates and the total number of displaced persons are increasing in Bangladesh and India.

Natural resource management is important for climate change adaptation, as local people's livelihoods are closely connected with the resources available in local rivers, wetlands, forests and grasslands. Climate change policies and programs need to recognize this connection for fighting against the effects of climate change. In all deltas in the three countries, the sustainable use of land and other natural resources is prioritized in protecting ecosystems and community livelihoods. In this context, the governments of Bangladesh, Ghana and India are focused more on agricultural diversification and ecosystem management. In Bangladesh and Ghana, several legal provisions describe the recognition of environmental protection and conservation in protecting the livelihoods of coastal people. In Bangladesh, Environmental Impact Assessment (EIA) is mandatory before establishing any development project to avoid any potential harms to natural resources. In Ghana, legal provisions like Forest Act and Fisheries Act follow the norms in protecting the natural ecosystem. In India, the National Action Plan on Climate Change of 2008 states the dimension of natural resource management in terms of water resources, biodiversity and forests, and human health.

In all three countries, incorporating indigenous agricultural practices into farming systems has been deemed important, which would reduce the degradation of soil and water, and promote resilient and sustainable agriculture and natural resource conservation. Moreover, the strengthening of institutional capacities, improved social service delivery and new agricultural research have been identified as issues that need to be addressed by the policies in India (in IBD and MD). In Bangladesh, accountability and transparency, participation and effectiveness need to be strengthened in adaptation policies and programs. The legal provisions also need to recognize natural and cultural heritages, while addressing the question of how to mitigate or adapt to the effects of climate change. Furthermore, the absence of an international river basin agreement in the GBM also posed a major governance challenge for promoting natural resource management in Bangladesh.

The disaster management system is fairly strong in Bangladesh, guided by the National Plan for Disaster Management and the Standing Orders on Disasters (SoD). In the case of any major disaster in Bangladesh, these legal frameworks provide the guidelines for social protection of the different groups of people like women, children, the elderly and the disabled. However, women's concerns did not receive proper recognition in disaster response policies despite their representation in the decision-making and implementation process. The absence of any separate bathrooms and living spaces for women in the design of cyclone shelters is one example of this. The policy documents need to focus more on gendered adaptation concerns.

In summary, there are several strengths in the climate change governance frameworks in the three countries; but there are several weaknesses in the policy and legal frameworks as well, especially with regards to the extent to which climate change governance framework focuses on human rights, natural resources management and disaster response dimensions. There are some clear opportunities for formulating climate change-oriented development and social service programs based on an improved understanding of the vulnerability of the affected people (including gendered and distributional aspects) via fruitful and effective participation of the delta communities, and ensuring the integration of natural and cultural heritage specific to the geographical locations in question.

Author Contributions: M.A.H. developed the paper's framework and coordinated the co-authors' contributions accordingly. M.A.C. helped in developing the manuscript. M.S. and M.S.M. refined the framework with critical 
comments. M.S. also contributed significantly in improving the quality of the paper following the reviewers' comments. A.H. coordinated the write up of Indian Bengal Delta and Mahanadi Delta in India. A.P. and S.D. along with A.H. developed the draft sections of these two deltas. C.A.T. coordinated the team activities of V.D. in Ghana and proofread the final paper. W.N. and R.Q. along with C.A.T. developed the Volta part of the paper. A.A. designed the questionnaire for barrier survey and governance questions for policy analysis. He also reviewed the paper and improved the quality of the paper with critical comments.

Funding: International Development Research Centre: 107642.

Acknowledgments: This work was carried out under the DEltas, vulnerability and Climate Change: Migration and Adaptation (DECCMA) project which is part of Collaborative Adaptation Research Initiative in Africa and Asia (CARIAA), with financial support from the UK government's Department for International Development (DFID) and the International Development Research Centre (IDRC), Canada. The views expressed in this work are those of the creators and do not necessarily represent those of DFID and IDRC or its board of governors.

Conflicts of Interest: The authors declare no conflict of interest.

\section{References}

1. Harley, C.D.; Randall Hughes, A.; Hultegren, K.M.; Miner, B.G.; Sorte, C.J.; Thornder, C.S.; Rodrigguea, L.F.; Tomanek, L.; Williams, S.L. The impacts of climate change in coastal marine systems. Ecol. Lett. 2006, 9, 228-241. Available online: https://onlinelibrary.wiley.com/doi/full/10.1111/j.1461-0248.2005.00871.x (accessed on 10 June 2018). [CrossRef] [PubMed]

2. Nicholls, R.J.; Hutton, C.W.; Lazar, A.N.; Allan, A.; Adger, W.N.; Adams, H.; Wolf, J.; Rahman, M.; Salehin, M. Integrated assessment of social and environmental sustainability dynamics in the Ganges-Brahmaputra-Meghna delta, Bangladesh. Estuar. Coast. Shelf Sci. 2016, 183. [CrossRef]

3. Suckall, N.; Tompkins, E.L.; Nicholls, R.J.; Kebede, A.S.; Lázár, A.N.; Vincent, K.; Allan, A.; Chapman, A.; Rahman, R.; Ghosh, T.; et al. A framework for identifying and selecting long term adaptation policy directions for deltas. Sci. Total Environ. 2018, 633, 946-957. [CrossRef] [PubMed]

4. Intergovernmental Panel on Climate Change (IPCC). Climate Change 2014: Synthesis Report. Contribution of Working Groups I, II and III to the Fifth Assessment Report of the Intergovernmental Panel on Climate Change; Pachauri, R.K., Meyer, L.A., Eds.; IPCC: Geneva, Switzerland, 2014; p. 151.

5. Miller, F.; Thomalla, F.; Rockström, J. Paths to a sustainable recovery after the tsunami. Sustain. Dev. Update 2005, 5, 2-3.

6. Sachs, W. Climate Change and Human Rights. Development 2008, 51, 332-337. [CrossRef]

7. Adger, W.N.; Arnell, N.W.; Tompkins, E.L. Successful adaptation to climate change across scales. Glob. Environ. Chang. 2005, 15, 77-86. Available online: https://pdfs.semanticscholar.org/9d23/ c71126cdc5c54cb5f3d170fc68e06bdd3c7c.pdf (accessed on 12 May 2018). [CrossRef]

8. O'Brien, G.; O'Keefe, P.; Rose, J.; Wisner, B. Climate change and disaster management. Disasters 2006, 30, 64-80. Available online: https://onlinelibrary.wiley.com/doi/pdf/10.1111/j.1467-9523.2006.00307.x (accessed on 15 July 2018). [CrossRef] [PubMed]

9. Christoplos, I.; Anderson, S.; Arnold, M.; Galaz, V.; Hedger, M.; Klein, R.J.; Goulven, K.L. The Human Dimension of Climate Adaptation: The Importance of Local and Institutional Issues; Commission on Climate Change and Development: Stockholm, Sweden, 2009.

10. Kok, M.T.J.; De Coninck, H.C. Widening the scope of policies to address climate change: Directions for mainstreaming. Environ. Sci. Policy 2008, 10, 587-599. [CrossRef]

11. Urwin, K.; Jordan, A. Does Public Policy Support or Undermine Climate Change Adaptation? Exploring Policy Interplay across Different Scales of Governance. Glob. Environ. Chang. 2008, 18, 180-191. [CrossRef]

12. Adger, W.N.; Barnett, J.; Brown, K.; Marshall, N.; O’Brien, K. Cultural Dimensions of Climate Change Impacts and Adaptation. Nat. Clim. Chang. 2012, 112-117. [CrossRef]

13. Tacoli, C. Crisis or Adaptation? Migration and Climate Change in a Context of High Mobility. Environ. Urban. 2009, 21, 513-525. [CrossRef]

14. Knox, J.H. Linking Human Rights and Climate Change at the United Nations. Harv. Environ. Law Rev. 2009, 33, 478-498.

15. Kravchenko, S. Right to Carbon or Right to Life: Human Rights Approaches to Climate Change. Vt. J. Environ. Law 2008, 9, 513-547. [CrossRef] 
16. McLeman, R.A.; Hunter, L.M. Migration in the Context of Vulnerability and Adaptation to Climate Change. Wires Clim. Chang. 2010, 1. [CrossRef]

17. Hoppe, R.; Wesselink, A.; Cairns, R. Lost in the Problem: The Role of Boundary Organizations in the Governance of Climate Change. Wires Clim. Chang. 2013, 4, 283-300. [CrossRef]

18. Griffiths, A.; Haigh, N.; Rassias, J. A Framework for Understanding Instiutional Governance Systems and Climate Change: The Case of Australia. Eur. Manag. J. 2007, 25, 415-427. [CrossRef]

19. Camacho, A.E. Adaptive Governance to Climate Change: Managing Uncertainty through a Learning Infrastructure. Emory Law J. 2009, 59, 1-79.

20. Quay, R. Anticipatory Governance: A Tool for Climate Change Adaptation. J. Am. Plan. Assoc. 2010, 76, 496-511.

21. Intergovernmental Panel on Climate Change (IPCC). Climate Change 1990: The IPCC Scientific Assessment. Contribution of Working Groups I, II and III to the First Assessment Report of the Intergovernmental Panel on Climate Change; Houghton, J.T., Jenkins, G.J., Ephraums, J.J., Eds.; Cambridge University Press: Cambridge, UK, 1990; Available online: https://www.researchgate.net/publication/281526599_Contribution_of_working_groups_ I_II_and_III_to_the_fourth_assessment_report_of_the_intergovernmental_panel_on_climate_change (accessed on 13 February 2019).

22. Boncour, P.; Burson, B. Climate Change and Migration in the South Pacific Region: Policy Perspectives. Policy Q. 2009, 5, 13-20. [CrossRef]

23. Addo, K.A.; Nicholls, R.J.; Codjoe, S.N.A.; Abu, M. A Biophysical and Socioeconomic Review of the Volta Delta, Ghana. J. Coast. Res. 2016. [CrossRef]

24. Mukhopadhyay, A.; Ghosh, P.; Chanda, A.; Ghosh, A.; Ghosh, S.; Das, S.; Ghosh, T.; Hazra, S. Threats to coastal communities of Mahanadi delta due to imminent consequences of erosion-Present and near future. Sci. Total Environ. 2018, 637, 717-729. [CrossRef]

25. Cazcarro, I.; Arto, I.; Hazra, S.; Bhattacharya, R.N.; Adjei, P.O.; Ofori-Danson, P.K.; Asenso, J.K.; Amponsah, S.K.; Khondker, B.; Raihan, S.; et al. Biophysical and Socioeconomic State and Links of Deltaic Areas Vulnerable to Climate Change: Volta (Ghana), Mahanadi (India) and Ganges-Brahmaputra-Meghna (India and Bangladesh). Sustainability 2018, 10, 893. [CrossRef]

26. Ncube, S.; Hissen, N.; Sayan, R.C.; Allan, A.; Spray, C.; Tompkins, E.; Suckall, N.; Vincent, K.; Salehin, M.; Ghosh, A.K.; et al. Barriers to climate change adaptation policy implementation. DECCMA Reports, Deltas, Vulnerability and Climate Change: Migration and Adaptation, IDRC Project Number 107642. 2017. Available online: www.deccma.com (accessed on 10 January 2019).

27. West Bengal State Action Plan on Climate Change; Department of Environment, Government of West Bengal: West Bengal, India, 2012.

28. Samling, C.L.; Das, S.; Hazra, S. Migration in the Indian Bengal Delta and the MahanadiDelta: A Review of the Literature; DECCMA Working Paper, Deltas, Vulnerability and Climate Change: Migration and Adaptation; IDRC Project Number 107642; Southampton, UK, 2015; Available online: www.deccma.com (accessed on 15 July 2018).

29. Akyeampong, E. Between the Sea and the Lagoon. An Eco-Social History of the Anlo of Southeastern Ghana, c.1850 to Recent Times (Western African Studies); Ohio University Press: Athens, OH, USA, 2001.

30. Afram, S.O.; Kwofie, T.E.; Attipoe, J. The influence of beneficiary participation in resettlement schemes in Ghana. In Proceedings of the 4th International Conference on Infrastructure Development in Africa, Kumasi, Ghana, 25-26 March 2015; Available online: https://www.researchgate.net/profile/Titus_Kwofie/ publication/276489311_THE_INFLUENCE_OF_BENFICIARY_PARTICIPATION_IN_RESETTLEMENT_ SCHEMES_IN_GHANA_A_Case_Study_of_the_Keta_Basin_Sea_Defence_Resettlement_Project/links/ 5559edb108ae6943a877c476/THE-INFLUENCE-OF-BENFICIARY-PARTICIPATION-IN-RESETTLEMENTSCHEMES-IN-GHANA-A-Case-Study-of-the-Keta-Basin-Sea-Defence-Resettlement-Project.pdf (accessed on 8 January 2018).

31. Danquah, J.A.; Attipoe, J.A.; Ankrah, J.S. Assessment of residential satisfaction in the resettlement towns of the Keta basin in Ghana. Int. J. Civ. Eng. Constr. Estate Manag. 2014, 2, $26-45$. Available online: http://www.eajournals.org/wp-content/uploads/Assessment-Of-Residential-SatisfactionIn-The-Resettlement-Towns-Of-The-Keta-Basin-In-Ghana.pdf (accessed on 19 June 2018).

32. Ministry of Health and Family Welfare (MoHFW). Resettlement Policy; Ministry of Health and Family Welfare. Government of the People's Republic of Bangladesh: Dhaka, Bangladesh, 2015. 
33. Ministry of Environment and Forest (MOEF). Bangladesh Environment Conservation Act 1995; Governments of the People's Republic of Bangladesh: Dhaka, Bangladesh, 1995.

34. The Bangladesh Wildlife (Preservation) Order. President's order no. 23 of 1973. 1973. Available online: http://bdlaws.minlaw.gov.bd/print_sections_all.php?id=452 (accessed on 3 April 2017).

35. National Action Plan on Climate Change; Prime Minister's Council on Climate Change, Ministry of Environment, Forests and Climate Change: New Delhi, India, 2008; Available online: http://www.moef.nic.in/ccd-napcc (accessed on 4 March 2018).

36. Government of India. National Environment Policy Approved by the Union Cabinet on 18 May 2006; Ministry of Environment and Forests: New Delhi, India, 2006.

37. Odisha Climate Change Action Plan 2015-2020 (Draft); Climate Change Cell, Department of Forest and Environment: India, 2015. Available online: http://limatechangecellodisha.org/pdf/Odisha_SAPCC_20162020.pdf (accessed on 3 March 2019).

38. Ministry of Rural Development (MoRD). The Mahatma Gandhi National Rural Employment Guarantee Act; Ministry of Rural Development, Government of India: New Delhi, India, 2005.

39. MoA. State Agriculture Plan for West Bengal (2009); Ministry of Agriculture, Government of India: New Delhi, India, 2009.

40. National Water Act 2013; Government of the People's Republic of Bangladesh: Dhaka, Bangladesh, 2013.

41. Bangladesh Climate Change Gender Action Plan 2013; Government of the People's Republic of Bangladesh: Dhaka, Bangladesh, 2013.

42. International Environmental Agreements (IEA). Convention on the status of the establishment of Volta Basin Authority (2007). Accessed from the International Environmental Agreements Database Project. 2016. Available online: https://iea.uoregon.edu/treaty-text/2007-voltabasinauthorityentxt (accessed on 11 September 2018).

43. Ministry of Disaster Management and Relief (MoDMR). National Plan for Disaster Management 2010-2015 (2010); Government of the People's Republic of Bangladesh: Dhaka, Bangladesh, 2010.

44. Rajdhani Unnayan Kartripakkha (RAJUK). Dhaka Mahanagar Building Construction, Development, Protection and Removal Rule' 2008; Ministry of housing and public work: Dhaka, Bangladesh, 2008; Available online: http://www.rajukdhaka.gov.bd/rajuk/page/web/devcontrol/DhakaImaratNirmanBidhimala-2008.pdf (accessed on 2 May 2016).

45. Ministry of Food and Disaster Management (MoFDM). Standing Orders on Disaster 2010; Government of the People's Republic of Bangladesh: Dhaka, Bangladesh, 2010.

46. Mishra, D.; Sahu, N.C. Response of farmers to climate change in Odisha: An empirical investigation. Int. J. Environ. Sci. 2014, 4, 786-800.

47. Ghosh, A.K.; Hazra, S.; Samling, C.L. Resettlement and Rehabilitation: Indian Scenario; DECCMA Working Paper, Deltas, Vulnerability and Climate Change: Migration and Adaptation; IDRC Project Number 107642; Southampton, UK, 2015; Available online: www.deccma.com (accessed on 15 July 2018).

(C) 2019 by the authors. Licensee MDPI, Basel, Switzerland. This article is an open access article distributed under the terms and conditions of the Creative Commons Attribution (CC BY) license (http://creativecommons.org/licenses/by/4.0/). 